\title{
TRICHOCYTES IN LITHOPHYLLUM KOTSCHYANUM AND LITHOPHYLLUM SPP. (CORALLINALES, RHODOPHYTA) FROM THE NW INDIAN OCEAN ${ }^{1}$
}

\author{
Basso Daniela, ${ }^{2}$ Caragnano Annalisa \\ Dip.to di Sc. dell'Ambiente e del Territorio e di Scienze della Terra, Sez. di Sc. Geologiche e Geotecnologie, Università degli \\ Studi di Milano-Bicocca, Piazza della Scienza 4, Milano 20126, Italy \\ and Rodondi Graziella
}

Dip.to di Bioscienze, Università degli Studi di Milano, Via Celoria 26, Milano 20133, Italy

The current diagnosis of the genus Lithophyllum includes absent or rare trichocyte occurrence. After examining holotype material, single trichocytes have been revealed to occur abundantly in Lithophyllum kotschyanum Unger, and in freshly collected specimens of Lithophyllum spp. from the Red Sea, Gulf of Aden and Socotra Island (Yemen). Trichocyte occurrence is not considered a diagnostic character at specific or supraspecific levels in the Lithophylloideae, and the ecological significance of trichocyte formation is discussed. The generitype species, L. incrustans Philippi, does not show trichocytes nor do many other Lithophyllum species from diverse geographic localities, but the presence of abundant trichocytes in other congeneric taxa requires emendation of the genus diagnosis. Therefore, the diagnosis of Lithophyllum is here emended by eliminating the adjective "rare" in the sentence concerning trichocyte occurrence, as follows: "Trichocytes present or absent, if present occurring singly."

Key index words: coralline algae; holotype; Indian Ocean; Lithophyllum kotschyanum; Red Sea; TRH; trichocyte; Unger

According to the current description and delimitation of Lithophyllum Philippi (Harvey et al. 2009), trichocytes (=hair-bearing cells) are not a common feature, and when present, they occur singly (Keats 1995, 1997, Guiry and Guiry 2014). No trichocytebearing Lithophyllum has been described from the Red Sea and Indian Ocean. Among the most common Lithophyllum species recorded in this area, $L$. kotschyanum Unger is considered to be widely distributed across the tropical Red Sea and Indo-Pacific Ocean (Silva et al. 1996). In the framework of a large-scale investigation on corallines from these localities, we collected some common Lithophyllum specimens bearing abundant trichocytes. Ongoing morphological and molecular studies suggest multiple species are passing under L. kotschyanum and

\footnotetext{
${ }^{1}$ Received 29 November 2013. Accepted 21 April 2014.

${ }^{2}$ Author for correspondence: e-mail daniela.basso@unimib.it.

Editorial Responsibility: P. Gabrielson (Associate Editor)
}

highlight the need to verify all previous reports of this species in the literature. This article presents the results and implications of an anatomical investigation of the holotype of L. kotschyanum and other freshly collected Lithophyllum specimens from Red Sea and Indo-Pacific and discusses the occurrence of trichocytes in Lithophyllum.

\section{MATERIALS AND METHODS}

Specimens were collected at several localities along the SE Sinai coast of Egypt, along the Yemeni coast of the Red Sea, Gulf of Aden, and Socotra, and in the Persian Gulf, and were deposited in MI (abbreviations after Thiers 2014). A selection of the new thin sections obtained from the holotype of L. kotschyanum were deposited in TRH.

Material examined. Red Sea: Nakhlet El Tall, Sinai peninsula, 0.6-1 m (leg. Basso: DB555-558, DB673, 5.x.2006); Ras Mohammed, Sinai peninsula, $0.6 \mathrm{~m}$ (leg. Basso: DB578, 9.v.2007); Ras Ghamila lagoon, Sinai peninsula, $1 \mathrm{~m}$ (leg. Caragnano: DB573, 18.x.2009; DB 637-638, 24.iv.2008); Yemen, Kamaran, 1 m (leg. Caragnano: DB574, 2.x.2009); 1.5 m (leg. Caragnano: DB575-576, 28.ix.2009); Indian Ocean: Persian Gulf, Kuwait, Qaro, 5 m (leg. Benzoni: DB672, 24.ix.2002); Aden Gulf, Yemen, Bahlaf, 2-3 m (leg. Benzoni: DB559, ix 2006; DB563, xi.2006; leg. Caragnano: DB567-570, iii.2008; DB657, DB659, DB660, DB692, xi.2008); Yemen, Socotra Is.: Shalintaitin, $9 \mathrm{~m}$ (leg. Caragnano: DB612, iii.2010); Rosh, $16 \mathrm{~m}$ (leg. Caragnano: DB615-616, 12.iii.2010); Ras Adho, 22 m, 13 m (leg. Caragnano: DB636, 16.iii.2010). Corallines were air dried prior transport to the Milan facilities. The holotype of L. kotschyanum (leg. Kotschy: TRH A20-1272, Bahrain Gulf, Persian Gulf) was also examined (Fig. 1).

Air-dried specimens for SEM were fractured and mounted on aluminum stubs with silver glue. Samples were gold coated (15 nm in thickness) and examined in a SEM Vega Tescan TS5136XM at $20 \mathrm{kV}$ at the Milano-Bicocca facilities.

For LM, pieces of thallus were decalcified with Tellyesniczkyi's solution (Bressan 1974) for 12-48 h, washed in distilled water, dehydrated through a graded ethanol series and embedded in methacrylate resin (Technovit 7100; Heraeus Kulzer, Wehrheim, Germany). Preparation of serial sections follows Basso and Rodondi (2006). Permanent slides for LM were examined and photographed with a Leica DMRB photomicroscope.

Anatomical terminology follows Adey and Adey (1973) and Woelkerling (1988). Conceptacle measurements follow the system of Adey and Adey (1973) and were made directly from the SEM or under LM using a calibrated eyepiece micrometer. Cell measurements follow Basso et al. (2004). 

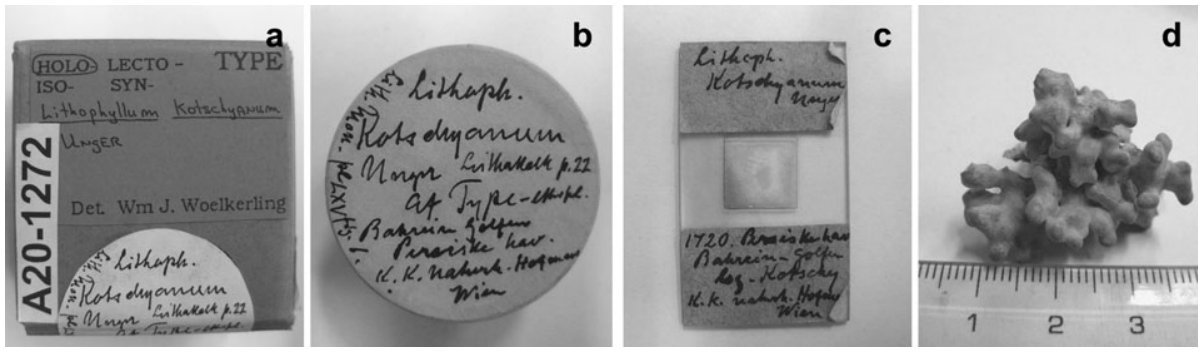

FIG. 1. Holotype collection of Lithophyllum kotschyanum Unger in TRH: (a and b) boxes reporting details of collection; (c) petrographic thin section 1720; (d) holotype specimen.
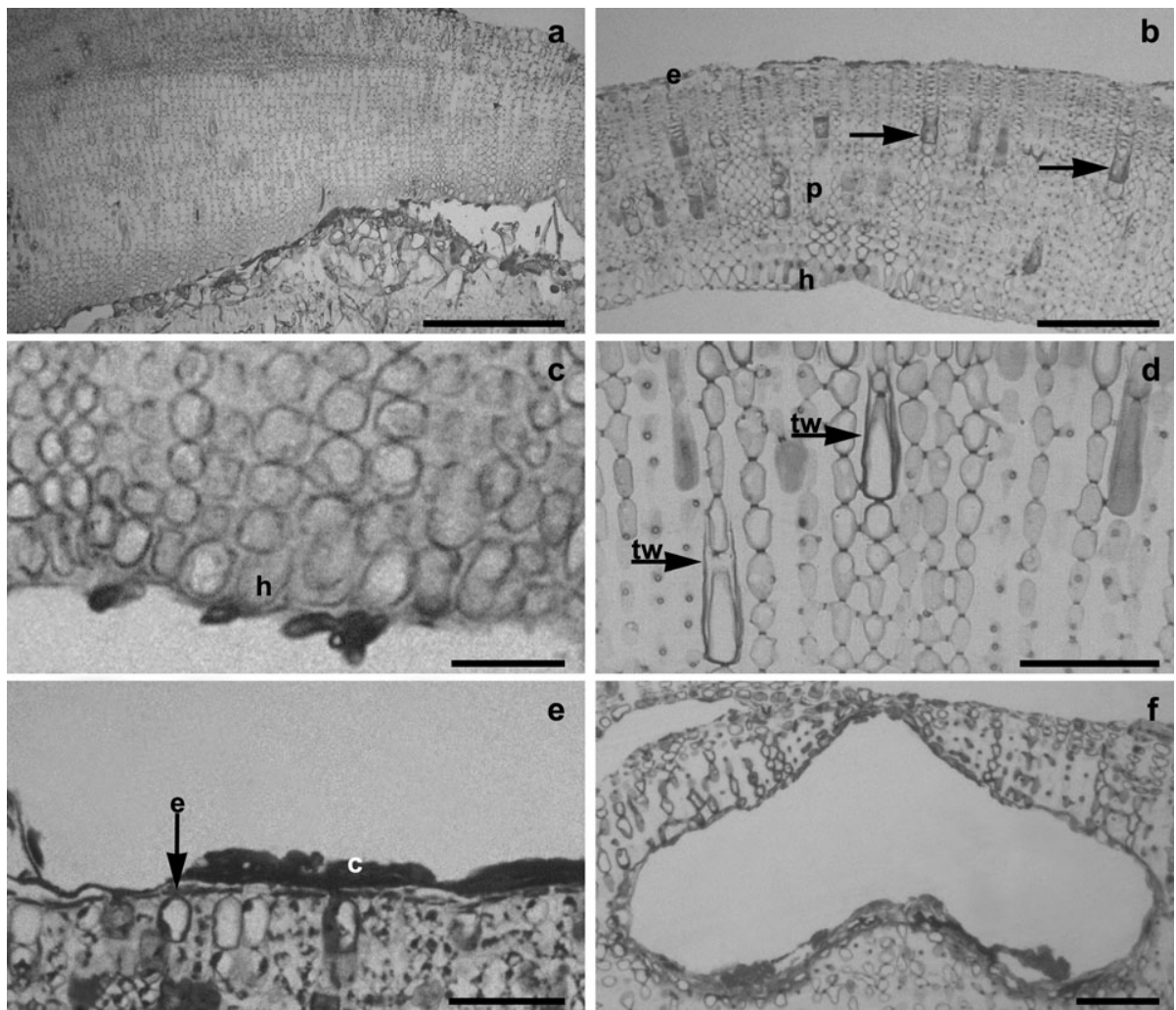

FIG. 2. Histological sections of Lithophyllum kotschyanum Unger holotype in TRH: (a) dimerous structure of vegetative portion of thallus, scale bar $=200 \mu \mathrm{m}$; (b) details of hypothallus (h), perithallus ( $p)$, and epithallial cells (e) showing abundant trichocytes (arrows), scale bar $=100 \mu \mathrm{m} ;$ (c) details of nonpalisade hypothallial cells (h) and absence of cell fusions, scale bar $=25 \mu \mathrm{m}$; (d) magnification of sac-like, buried trichocyte walls (tw, arrows), scale bar = $50 \mu \mathrm{m}$; (e) flattened epithallial cells (e with arrow) and cuticle (c), scale bar $=50 \mu \mathrm{m}$; (f) Uniporate presumed tetraspo-rangial conceptacle chamber with convex-up floor (columella), scalebar $=50 \mu \mathrm{m}$.

\section{RESULTS}

Lithophyllum kotschyanum Unger (1858: 22, pl. V, fig. 15)

Holotype: TRH, A20-1272 (Trondheim, Norway, Woelkerling 1993:133), Figs. 1 and 2, including thin section no. 1720 (Woelkerling et al. 2005).

Etymology: the specific epithet is dedicated to the collector, Mr. Theodor Kotschy (Unger 1858, Woelkerling 1993:133).

Illustrations of type material: Printz 1929: pl. 65, fig. 1; Verheij 1994: 129, fig. 8.

Type locality: Gulf of Bahrain, Persian Gulf

Habitat: Plants encrusting corals and mollusks (Unger 1858). Habitat details unknown.

Geographic distribution: Lithophyllum kotschyanum as circumscribed here is known only from the type locality. Other occurrences from the literature require further confirmation after critical revision based on morphological and molecular investigations of the field-collected material.

Habit and vegetative structure: The holotype of L. kotschyanum (TRH A20-1272, Fig. 1d) is apparently a broken fragment of a larger plant, nonendophytic, with fruticose growth-form. Protuberances have a smooth surface, are cylindrical or slightly compressed, branched, up to $20 \mathrm{~mm}$ long and about 2-5 mm wide. Most protuberances terminate with a blunt apex, and some are fused at their distal ends (Fig. 1d).

Thallus pseudoparenchymatous, dimerous, with a basal or ventral layer of cells (=hypothallus) running parallel to the substrate (Fig. 2, a and b). Hypothallial cells $7-13 \mu \mathrm{m}$ long and $10-15 \mu \mathrm{m}$ in diameter (Fig. 2c). Perithallus composed of filaments of cells rising from the hypothallus and curv- 
ing outward toward the thallus surface, 8-31 $\mu \mathrm{m}$ long and $7-11 \mu \mathrm{m}$ in diameter (Fig. 2b). Cells of adjacent filaments joined by secondary-pit connections, cell fusions not observed (Fig. 2, c and d). Palisade cells not observed. Single trichocytes 30$40 \mu \mathrm{m}$ long and $12-14 \mu \mathrm{m}$ in diameter, abundantly distributed in the perithallus and at the thallus surface (Fig. 2, a, b, d, e). Trichocytes not observed in the hypothallus and in the oldest 4-5 perithallial cell filaments (those corresponding to the early stages of thallus development). The holotype material includes a thin petrographic section 1720 (Fig. 1c) that does not show trichocytes. Single epithallial cells flattened, $10-12 \mu \mathrm{m}$ in diameter and $2.5 \mu \mathrm{m}$ long (Fig. 2e). Epithallial cells overlain by a cuticle (Fig 2, b and e).

Reproduction: Empty uniporate conceptacle chamber in the holotype of L. kotschyanum, presumed tetrasporangial on the basis of shape and size (in agreement with Verheij 1994), slightly protruding above the surrounding thallus surface, becoming buried in the thallus, $310-380 \mu \mathrm{m}$ in diameter and $110-150 \mu \mathrm{m}$ high, with pore-canal $70-80 \mu \mathrm{m}$ long (Fig. 2f). Floor of the conceptacle chamber convex upward below a central columella. The conceptacle chamber floor is 16-17 cells below the thallus surface (Fig. 2f). Roof filaments 7 cells long, including the terminal epithallial cell (Fig. 2f). Gametangial and carposporangial conceptacles unknown.

Freshly collected Lithophyllum specimens. Freshly collected specimens of Lithophyllum spp. from the Red Sea, the Gulf of Aden, the Persian Gulf and Socotra show a pseuparenchymatous structure and dimerous organization of the thallus, whose thickness ranges from about $100 \mu \mathrm{m}$ to more than $1 \mathrm{~cm}$ of continuous thallus growth. Some specimens show superposition of conspecific thalli and have thickness exceeding $2 \mathrm{~cm}$. Cells of adjacent filaments linked by secondary-pit connections, no fusions observed. Tetrasporangia contained in uniporate conceptacles. All thalli possess abundant, scattered trichocytes, but these are apparently lacking from the hypothallus and first few cells of perithallial filaments (about 2-4; Fig 3, a-e). This pattern of trichocyte distribution appears unrelated to the total thickness of the thallus. SEM investigations of the same fresh material revealed very rare trichocytes in the perithallus (Fig. 3f), as well as at the surface of the algae (Fig. 3g).

\section{DISCUSSION}

Routine histological preparations of decalcified material, such as those used in the present study, easily allow the detection of trichocytes in coralline algae (Cabioch 1971, Johansen 1981, Chamberlain 1985, Woelkerling 1988, Afonso-Carrillo 1989, Penrose and Chamberlain 1993, Keats 1995, 1997). The type species of Lithophyllum is L. incrustans Phi- lippi, lectotypified with a specimen collected in Sicily (Woelkerling 1983). This lectotype was studied by histological sections, and no trichocytes were observed (Woelkerling 1983), in agreement with results from freshly collected plants of L. incrustans from the Mediterranean shallow subtidal of Ognina (Catania, Sicily; D. Basso, unpubl. data), and from the Atlantic (Cabioch 1969, Irvine and Chamberlain 1994).

Lithophyllum has been considered a genus of trichocyte-free species for more than 150 years (Woelkerling 1988). Trichocytes do not occur in recently revised Lithophyllum species from Brazil (Villas-Boas et al. 2009), Gulf of California (Riosmena-Rodríguez et al. 1999), Mediterranean Sea (Basso et al. 1996, Chamberlain 1997, Athanasiadis 1999, Bressan and Babbini 2003), British Isles (Irvine and Chamberlain 1994), Spermonde Archipelago (Verheij 1994), Hawai'i (Adey et al. 1982), southeastern Australia (Harvey et al. 2009), and New Zealand (Harvey et al. 2005, Farr et al. 2009). Few exceptions have been recently documented from Fiji, viz. common solitary trichocytes in the semiendophytic species Lithophyllum cuneatum Keats, and sporadic individual trichocytes in Lithophyllum insipidum Adey, Townsend et Boykins and Lithophyllum flavescens Keats (Keats 1995, 1997). In contrast, trichocytes occur abundantly in all Lithophyllum species from the Gulf of Aden, Persian Gulf and Socotra dealt in this article, although we could not find any literature report of trichocyte occurrence in L. kotschyanum. The holotype of L. kotschyanum was illustrated macroscopically by Printz (1929), and its anatomy was incompletely illustrated by Verheij (1994) based on a microphotograph of the petrographic section (=non decalcified material) that is part of the holotype (Verheij 1994, p. 129, fig. 8). Most subsequent reports are check-lists (Silva et al. 1996), and the few illustrated reports of L. kotschyanum are either based on petrographic sections (for example: Rasser and Piller 1997), or on material whose identity requires further investigation (such as Adey et al. 1982), since monophyly for this species is not supported by molecular data (Kato et al. 2011).

Three types of trichocyte development have been reported in coralline algae (Cabioch 1971, Johansen 1981). The Jania rubens type of trichocyte development (Johansen 1981, p. 33-35, fig. 18B) corresponds to our observations: an intercalary meristematic cell divides obliquely into two cells. The newly formed oblique wall does not become calcified (Fig. 3g), and the entire trichocyte is contained within the wall of the original meristematic cell. The distal cell of the trichocyte becomes modified by the formation of a hair (Fig. 3c) that grows out from the surface of the overlying epithallial cell which finally sloughs off (Fig. 3, c inset and h). When the hair withers, the proximal cell of the trichocyte becomes meristematic, producing new perithallial 


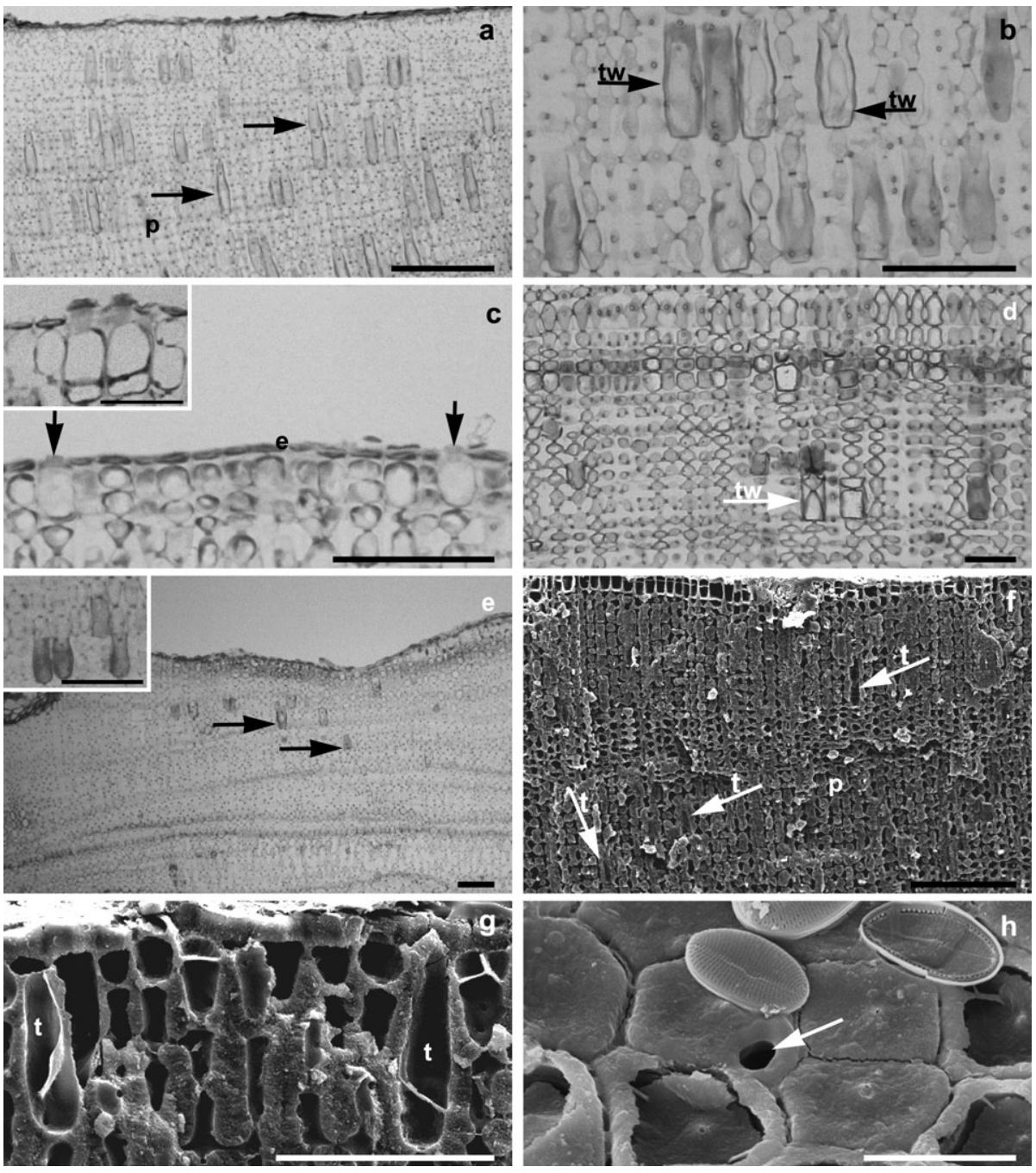

FIG. 3. Microscopic anatomy of freshly collected Lithophyllum specimens: (a-e) hystological sections; (f-h) SEM pictures; (a) abundant trichocytes (arrows) in perithallus (p) of sample DB673, scale bar $=50 \mu \mathrm{m}$; (b) details of remains of buried trichocyte walls (tw, arrows). Sample DB673, scale bar $=50 \mu \mathrm{m} ; \quad$ (c) flattened epithallial cells (e) and trichocytes (arrows), scale bar $=50 \mu \mathrm{m}$. Inset: magnification of superficial trichocytes, scale bar $=25 \mu \mathrm{m} ;(\mathrm{d})$ trichocytes buried in perithallus of DB657 with visible remains of buried, sac-like trichocyte walls (tw, arrow), scale bar $=50 \mu \mathrm{m}$; (e) trichocytes buried in perithallus of DB636 (arrows), scale bar $=200 \mu \mathrm{m}$, details in inset, scale bar $=50 \mu \mathrm{m}$; (f) trichocytes (t, arrows) in perithallus (p) of DB673, scale bar $=100 \mu \mathrm{m} ;(\mathrm{g})$ Two trichocytes (t) at surface of DB673. Note noncalcified oblique wall within trichocyte, scale bar $=50 \mu \mathrm{m} ;(\mathrm{h})$ Surface view of DB574 with epithallial cells and trichocyte opening (arrow), scale bar $=$ $10 \mu \mathrm{m}$.

cells and a new epithallial cell that replaces the penetrated one. Within the Jania type of trichocyte development, the final steps may result in the complete obliteration of the old trichocyte (Jania), or, alternatively, in the conservation of the open-ended sac-like trichocyte walls that remain visible below the meristem (Metagoniolithon; Johansen 1981). The latter case corresponds to our observations in Lithophyllum kotschyanum and Lithophyllum spp., based on hystological decalcified sections enhanced by the Toluidine blue stain (Figs. 2b and 3, a and b). On the contrary, the calcified walls of the newly formed perithallial cells merge with the remains of the trichocyte walls (Figs. $2 \mathrm{~d}$ and $3 \mathrm{~b}$ ) that are therefore obliterated or less apparent under SEM (Fig. 3f) and in petrographic thin sections (Rasser and Piller 1997). This process explains why trichocytes were not detected in the petrographic section included in the holotype material and went overlooked (Verheij 1994, fig. 8). Given the difficulty to detect Lithophyllum trichocytes in petrographic sections and in SEM preparations, it is likely that they occur but were overlooked in other incompletely investigated species, besides those described in this article.

Environmental significance of trichocytes in coralline algae. On the basis of our current knowledge, trichocytes are considered lacking in the Sporolithales, despite some rare reports (Townsend et al. 1995, fig. 5B). Within the Corallinales, they commonly occur in many species of Neogoniolithon Setchell et Mason, Hydrolithon (Foslie) Foslie, Porolithon Foslie, Fosliella Howe, and Pneophyllum Kützing (Cabioch 1968, Jones and Woelkerling 1984, Chamberlain 1985, Penrose and Woelkerling 1988, Townsend and Adey 1990, Maneveldt et al. 2008). Trichocytes seldom occur in Spongites Kützing and in the Hapalidiaceae (Adey 1964, Walker 1984, Woelkerling 1988, Keats and Chamberlain 1997, Harvey et al. 2003, Basso and Rodondi 2006, Kaleb et al. 2011, Peña et al. 2011).

Within Lithophylloideae, besides Lithophyllum (sensu Bailey 1999) trichocytes are reported in Titanoderma pustulatum var. confine (Suneson 1943, Chamberlain 1991, Kjøsterud 1997) and in T. corallinae (as Lithophyllum corallinae, Woelkerling and 
Campbell 1992), and are rather common in many geniculate species of the genus Amphiroa Lamouroux (Choi and Lee 1988, Kim 1990, 1991). Also the geniculate species of the Corallinoideae commonly show trichocytes (Johansen 1981, Garbary and Johansen 1982, Choi and Lee 1988, Judson and Pueschel 2002). Further details and a synopsis of the literature with respect to the trichocyte type in the different coralline genera were provided by Townsend and Adey (1990). Even within this coarse survey, it is apparent that most coralline taxa have the capability to produce trichocytes, but the possibility of trichocyte phenotypical expression is much higher in some taxa than in others. Trichocyte occurrence and organization were considered diagnostic characters at the genus level (among others: Gordon et al. 1976, Adey et al. 1982), and it has been recently shown that the constant occurrence of trichocytes in horizontal fields is diagnostic of the resurrected genus Porolithon, in association with other characters (Kato et al. 2011). Moreover, the position of hypothallial trichocytes has been considered a valid character, in combination with others, to separate Pneophyllum from Hydrolithon (as Fosliella: Jones and Woelkerling 1984, Chamberlain 1985, Townsend and Adey 1990). However, whether the occurrence, position and organization of trichocytes is genetically rather than environmentally constrained is still largely unexplored, and most reports regard trichocytes as an inconsistent character for segregating species (Woelkerling 1988, RiosmenaRodríguez and Siqueiros-Beltrones 1996, Womersley 1996, Bressan and Babbini 2003, Harvey et al. 2005, Kim et al. 2007).

Different hypotheses have been formulated on the role of trichocytes in coralline algae. Trichocyte formation in Fosliella and Pneophyllum has been correlated to relatively high temperature and light intensity in laboratory studies and in the field (Bressan and Tomini 1982, Jones and Woelkerling 1984, Chamberlain 1985), thus suggesting a role of protection against excessive insolation. However, this explanation is contradicted by observed abundant trichocytes in deeply growing species, or in dim-lit conditions, where light could be a limiting factor rather than a possible damage (Walker 1984, Chamberlain 1985, Caragnano et al. 2014). Moreover, trichocytes are too short-lived and unevenly distributed to serve as a light screen above the thallus surface; therefore this hypothesis seems unlikely.

Another possible function of trichocytes would be to enhance nutrient absorption by increasing surface area (DeBoer and Whoriskey 1983). This theory is supported by the rapid decrease of nitrogen coincident with the months of maximum insolation and the formation of trichocytes (Chamberlain 1985), and by the observation that corallines grown in static seawater produce more trichocytes than their conspecifics cultured with a constant supply of through-flowing seawater (Walker 1984). Fast grow- ing corallines, typical of low latitudes, would require trichocytes to satisfy their increased nutrient requirements in reef oligotrophic waters (Walker 1984). Intra- and interspecific comparisons of trichocyte production in the natural environment and under controlled conditions are necessary to test this hypothesis.

Implications for the diagnosis of the genus Lithophyllum. The anatomy of L. kotschyanum and Lithophyllum spp. fully corresponds to the circumscription of Lithophyllum as described by Harvey et al. (2009), with the exception of trichocytes occurring singly but very abundantly both in the type material and in the fresh collections from the Red Sea and Indian Ocean. Pending further studies, the occurrence of trichocytes is not considered a diagnostic character for the segregation of species or supraspecific taxa within the Lithophylloideae. The generitype species, L. incrustans, does not show trichocytes, as also found in many Lithophyllum species worldwide. However, the occurrence of abundant trichocytes in other species requires that they be included in the genus diagnosis. Therefore, the diagnosis of Lithophyllum provided by Harvey et al. (2009) is here emended solely in the sentence: "Trichocytes present or absent, if present rare and occurring singly," by eliminating the adjective "rare," as follows: "Trichocytes present or absent, if present occurring singly."

The authors are grateful to The National Park of Egypt, South Sinai Sector (NCS/EEAA) and the Environmental Protection Authority (EPA) of Socotra for field work permit. We acknowledge the Coral Beach diving center (Sinai) and Fouad Naseeb (EPA Socotra) for logistic assistance. We also thank Robert Hirst and Yemen LNG, Claude Chaineu and Total E\&P, for allowing fieldwork and sampling, and Eric Dutrieux and Créocean for logistic and organization support. We thank S. Basheen (Professional Divers, Yemen) for his help in field work and Francesca Benzoni for exciting scientific discussions and sampling contribution. We are grateful to Tommy Prestø and Kristian Hassel, Herbarium TRH, for providing specimens from the collections in Trondheim, Norway. SEM pictures were provided by Paolo Gentile, SEM-EDS laboratory of Milano-Bicocca University. We are grateful to P. Gabrielson and two anonymous referees for their critical comments on a first draft of the manuscript. AC was funded through the $\mathrm{PhD}$ program of the Milan-Bicocca University. DB acknowledges FAR funding from Milano-Bicocca University.

Adey, W. H. 1964. The genus Phymatolithon in the Gulf of Maine. Hydrobiologia 24:377-420.

Adey, W. H. \& Adey, P. J. 1973. Studies on the biosystematics and ecology of the epilithic crustose Corallinaceae of the British Isles. Br. Phycol. J. 8:343-407.

Adey, W. H., Townsend, R. A. \& Boykins, W. T. 1982. The crustose coralline algae (Rhodophyta: Corallinaceae) of the Hawaiian Islands. Smithson. Contrib. Mar. Sci. 15:74.

Afonso-Carrillo, J. 1989. Morphology, anatomy and vegetative reproduction of Fosliella paschalis (Corallinaceae, Rhodophyta). Phycologia 28:331-41.

Athanasiadis, A. 1999. Mesophyllum macedonis, nov. sp. (Rhodophyta, Corallinales), a putative Tethyan relic in the north Aegean Sea. Eur. J. Phycol. 34:239-52. 
Bailey, J. C. 1999. Phylogenetic positions of Lithophyllum incrustans and Titanoderma pustulatum (Corallinaceae, Rhodophyta) based on 18S rRNA gene sequence analyses, with a revised classification of the Lithophylloideae. Phycologia 38:208-16.

Basso, D., Fravega, P. \& Vannucci, G. 1996. Fossil and living corallinaceans related to the Mediterranean endemic species Lithophyllum racemus (Lamarck) Foslie. Facies 35:275-92.

Basso, D. \& Rodondi, G. 2006. A Mediterranean population of Spongites fruticulosus (Rhodophyta, Corallinales), the type species of Spongites, and the taxonomic status of S. stalactitica and S. racemosa. Phycologia 45:403-16.

Basso, D., Rodondi, G. \& Mari, M. 2004. A comparative study between Lithothamnion minervae and the type material of Millepora fasciculata (Corallinales, Rhodophyta). Phycologia 43:215-23.

Bressan, G. 1974. Rodoficee calcaree dei mari italiani. Boll. Soc. Adr. Sc. 59:1-132.

Bressan, G. \& Babbini, L. 2003. Biodiversità marina delle coste Italiane. Corallinales del Mar Mediterraneo: guida alla determinazione. Biol. Mar. Medit. 10 (Suppl. 2):1-237.

Bressan, G. \& Tomini, I. 1982. Quelques observations sur la croissance des algues rouges calcaires du genre Fosliella (Rhodophycophyta, Corallinaceae). Vie et Milieu 31:283-91.

Cabioch, J. 1968. Sur le mode de formation des trichocytes chez le Neogoniolithon notarisii (Dufour) Setchell et Mason. C. R. Acad. Sc. Paris Série D 266:333-6.

Cabioch, J. 1969. Persistance de stades juvéniles et possibilité d'une néoténie chez Lithophyllum incrustans Philippi. C. R. Hebd. Séances Acad. Sci. Paris. Série D 268:497-500.

Cabioch, J. 1971. Etude sur les Corallinacées. 1. Caractères generaux de la cytologie. Cah. Biol. Mar. 12:121-86.

Caragnano, A., Basso, D., Jacob, D. E., Storz, D., Rodondi, G., Benzoni, F. \& Dutrieux, E. 2014. The coralline red alga Lithophyllum kotschyanum $\mathrm{f}$. affine as proxy of climate variability in the Yemen coast, Gulf of Aden (NW Indian Ocean). Geochim. Cosmochim. Acta 124:1-17.

Chamberlain, Y. M. 1985. Trichocyte occurrence and phenology in four species of Pneophyllum (Rhodophyta, Corallinaceae) from the British Isles. Br. Phycol. J. 20:375-9.

Chamberlain, Y. M. 1991. Historical and taxonomic studies in the genus Titanoderma (Rhodophyta, Corallinales) in the British Isles. Bull. Br. Mus. (Nat. Hist.) Bot. Ser. 21:1-80.

Chamberlain, Y. M. 1997. Observations on Lithophyllum lichenoides Philippi (Rhodophyta, Corallinaceae) and its reproductive structures. Cryptogamie Algol. 18:139-49.

Choi, D. S. \& Lee, I. K. 1988. On surface structures of Amphiroa (Corallinaceae, Rhodophyta). Algae 3:111-7.

DeBoer, J. A. \& Whoriskey, F. G. 1983. Production and role of hyaline hairs in Ceramium rubrum. Mar. Biol. 77:229-34.

Farr, T., Broom, J., Hart, D., Neill, K. \& Nelson, W. 2009. Common coralline algae of northern New Zealand: an identification guide. NIWA Information Series No. 70, 125 pp.

Garbary, D. J. \& Johansen, H. W. 1982. Scanning electron microscopy of Corallina and Haliptilon (Corallinaceae, Rhodophyta): surface features and their taxonomic implications. J. Phycol. 18:211-9.

Gordon, G. D., Masaki, T. \& Akioka, H. 1976. Floristic and distributional account of the common crustose coralline algae of Guam. Micronesica 12:247-77.

Guiry, M. D. \& Guiry, G. M. 2014. AlgaeBase. World-wide electronic publication, National University of Ireland, Galway. Available at: http://www.algaebase.org; searched on 3 February 2014.

Harvey, A. S., Broadwater, S. T., Woelkerling, W. J. \& Mitrovski, P. J. 2003. Choreonema (Corallinales, Rhodophyta): 18S rDNA phylogeny and the resurrection of the Hapalidaceae for the subfamilies Choreonematoideae, Austrolithoideae and Melobesioideae. J. Phycol. 39:988-98.

Harvey, A. S., Woelkerling, W. J., Farr, T., Neill, K. \& Nelson, W. 2005. Coralline algae of central New Zealand. NIWA Information Series No. 57, 145 pp.

Harvey, A. S., Woelkerling, W. J. \& Millar, A. J. K. 2009. The genus Lithophyllum (Lithophylloideae, Corallinaceae, Rhodo- phyta) in south-eastern Australia, with the description of L. riosmenae, sp. nov. Aust. Syst. Bot. 22:296-317.

Irvine, L. M. \& Chamberlain, Y. M. 1994. Seaweeds of the British Isles. Volume 1 Rhodophyta Part 2B Corallinales, Hildenbrandiales. The Natural History Museum, HMSO Publications, London, $276 \mathrm{pp}$.

Johansen, H. W. 1981. Coralline Algae, a First Synthesis. CRC Press, Boca Raton, Florida, 239 pp.

Jones, P. L. \& Woelkerling, W. J. 1984. An analysis of trichocyte and spore germination attributes as taxonomic characters in the Pneophyllum-Fosliella complex (Corallinaceae, Rhodophyta). Phycologia 23:183-94.

Judson, B. L. \& Pueschel, C. M. 2002. Ultrastructure of trichocyte (hair cell) complexes in Jania adhaerens (Corallinales, Rhodophyta). Phycologia 41:68-78.

Kaleb, S., Falace, A., Sartoni, G. \& Woelkerling, W. J. 2011. Morphology-anatomy of Mesophyllum macroblastum (Hapalidiaceae, Corallinales, Rhodophyta) in the Northern Adriatic Sea and a key to Mediterranean species of the genus. Cryptogamie Algol. 32:223-42.

Kato, A., Baba, M. \& Suda, S. 2011. Revision of the Mastophoroideae (Corallinales, Rhodophyta) and polyphyly in nongeniculate species widely distributed on Pacific coral reefs. J. Phycol. 47:662-72.

Keats, D. W. 1995. Lithophyllum cuneatum sp. nov. (Corallinaceae, Rhodophyta), a new species of non-geniculate coralline alga semi-endophytic in Hydrolithon onkodes and Neogoniolithon sp. from Fiji, South Pacific. Phycol. Res. 43:151-60.

Keats, D. W. 1997. Lithophyllum insipidum Adey, Townsend et Boykins and $L$. flavescens sp. nov.: two flat lithophylloid coralline algae (Corallinales, Rhodophyta) abundant in shallow reef environments in Fiji. Phycologia 36:351-65.

Keats, D. W. \& Chamberlain, Y. M. 1997. The non-geniculate coralline algae Synarthrophyton eckloniae (Foslie) comb. nov., and S. magellanicum (Foslie) comb. nov. (Rhodophyta) in South Africa including a comparison with relevant types. Eur. J. Phycol. $32: 55-79$.

Kim, S. 1990. Morphogenesis in Amphiroa (Corallinales, Rhodophyta): taxonomic implications. J. Phycol. 26(suppl.):4.

Kim, S. 1991. Secondary growth characteristic in Amphiroa (Corallinaceae, Rhodophyta) are useful in unraveling taxonomic problems. J. Phycol. 27(suppl.):39.

Kim, J. H., Guiry, M. D., Oak, J. H., Choi, D. S., Kang, S. H., Chung, H. \& Choi, H. G. 2007. Phylogenetic relationships within the tribe Janieae (Corallinales, Rhodophyta) based on molecular and morphological data: a reappraisal of Jania. J. Phycol. 43:1310-9.

Kjøsterud, A. B. 1997. Epiphytic coralline crusts (Corallinales, Rhodophyta) from South Norway. Sarsia 82:23-37.

Maneveldt, G. W., Chamberlain, Y. M. \& Keats, D. W. 2008. A catalogue with keys to the non-geniculate coralline algae (Corallinales, Rhodophyta) of South Africa. South African J. Bot. 74:555-66.

Peña, V., Adey, W. H., Riosmena-Rodríguez, R., Jung, M. Y., Afonso-Carillo, J., Choi, H. G. \& Bárbara, I. 2011. Mesophyllum sphaericum sp. nov. (Corallinales, Rhodophyta): a new maerlforming species from the northeast Atlantic. J. Phycol. 47:911-27.

Penrose, D. \& Chamberlain, Y. M. 1993. Hydrolithon farinosum (Lamouroux) comb. nov.: implications for generic concepts in the Mastophoroideae (Corallinaceae, Rhodophyta). Phycologia 32:295-303.

Penrose, D. \& Woelkerling, W. J. 1988. A taxonomic reassessment of Hydrolithon Foslie, Porolithon Foslie and Pseudolithophyllum Lemoine emend. Adey (Corallinaceae, Rhodophyta) and their relationships to Spongites Kützing. Phycologia 27:159-76.

Printz, H. 1929. M. Foslie Contributions to a Monograph of the Lithothamnia. K. Norske Vidensk. Selsk. Skr., Museet, Trondhjem, $60 \mathrm{pp}$.

Rasser, M. \& Piller, W. E. 1997. Depth distribution of calcareous encrusting associations in the northern Red Sea (Safaga, Egypt) and their geological implications. Proc. 8th Int. Coral Reef Sym. 1:743-8. 
Riosmena-Rodríguez, R. \& Siqueiros-Beltrones, D. A. 1996. Taxonomy of the genus Amphiroa (Corallinales, Rhodophyta) in the southern Baja California Peninsula, Mexico. Phycologia $35: 135-47$.

Riosmena-Rodríguez, R., Woelkerling, W. J. \& Foster, M. S. 1999. Taxonomic reassessment of rhodolith-forming species of Lithophyllum (Corallinales, Rhodophyta) in the Gulf of California, Mexico. Phycologia 38:401-17.

Silva, P. C., Basson, P. W. \& Moe, R. L. 1996. Catalogue of the benthic marine algae of the Indian Ocean. Univ. Cal. Pub. Bot. 79:1-1259.

Suneson, S. 1943. The structure, life-history and taxonomy of the Swedish Corallinaceae. Lunds Univ. Arsskr. N. F. Avd. 239:1-66.

Thiers, B. 2014. Index Herbariorum: a global directory of public herbaria and associated staff. New York Botanical Garden's Virtual Herbarium, New York. Available at: http://sweetgum. nybg.org/ih/

Townsend, R. A. \& Adey, W. H. 1990. Morphology of the Caribbean Alga: Goniolithon improcerum Foslie et Howe in Foslie (Corallinaceae, Rhodophyceae). Bot. Mar. 33:99-116.

Townsend, R. A., Woelkerling, W. J., Harvey, A. S. \& Borowitzka, M. 1995. An account of the red algal genus Sporolithon (Sporolithaceae, Corallinales) in southern Australia. Aust. Syst. Bot. 8:85-121.

Unger, F. 1858. Beiträge zur näheren Kenntniss des Leithakalkes, namentlich der vegetabilischen Einschlüsse und der Bildungsgeschichte desselben. Denkschriften der Kaiserlichen Akademie der Wissenschaften, Mathematisch-Naturwissenschaftliche Classe 14:13-35.
Verheij, E. 1994. Nongeniculate Corallinaceae (Corallinales, Rhodophyta) from the Spermonde Archipelago, SW Sulawesi, Indonesia. Blumea 39:95-137.

Villas-Boas, A. B., Riosmena-Rodríguez, R., Amado-Filho, G. M., Maneveldt, G. \& de O. Figueiredo, M. A. 2009. Rhodolithforming species of Lithophyllum (Corallinales; Rhodophyta) from Espírito Santo State, Brazil, including the description of $L$. depressum sp. nov. Phycologia 48:237-48.

Walker, R. 1984. Trichocytes and megacells in cultured crusts of three British species of Lithothamnium and Phymatolithon (Corallinaceae, Rhodophyta). Bot. Mar. 27:161-8.

Woelkerling, W. J. 1983. A taxonomic reassessment of Lithophyllum (Corallinaceae, Rhodophyta) based on studies of R.A. Philippi's original collections. Br. Phycol. J. 18:299-328.

Woelkerling, W. J. 1988. The Coralline Red Algae: An Analysis of the Genera and Subfamilies of Nongeniculate Corallinaceae. British Museum (Natural History) Oxford University Press, London, 268 pp.

Woelkerling, W. J. 1993. Type collections of Corallinales (Rhodophyta) in the Foslie Herbarium (TRH). Gunneria 67:1-289.

Woelkerling, W. J. \& Campbell, S. J. 1992. An account of Southern Australian species of Lithophyllum (Corallinaceae, Rhodophyta). Bull. Br. Mus. (Nat. Hist.) Bot. Ser. 22:1-107.

Woelkerling, W. J., Gustavsen, G., Myklebost, H. E., Prestø, T. \& Såstad, S. 2005. The coralline red algal herbarium of Mikael Foslie: revised catalogue with analyses. Gunneria 77:1-625.

Womersley, H. B. S. 1996. The Marine Benthic Flora of Southern Australia. Rhodophyta, Part IIIB. Australian Biological Resources Study, Canberra, Australia, 392 pp. 